unfortunately never became available on a commercial basis. After retirement from his University Readership in 1993, he continued working with the ion probe, also on the development of a high-intensity focused X-ray source for use in X-ray diffractometers (in association with Bede Scientific Ltd).

As well as supervising a series of $\mathrm{PhD}$ students in the course of the developments described above, Jim played a full part in undergraduate teaching and other departmental activities. He was a member of the Mineralogical Society for more than 40 years and served on the Council from 1984 to 1986 . The Society honoured him with a dedicated session at the Winter Meeting in January 1998 at which he received a special presidential award.
Jim was notable for the generosity with which he gave his time to others, and this extended to various activities in his home village of Haslingfield, where he served as parish councillor and school governor, while still finding time to carry out extensive renovations on the old farmhouse acquired in a near-derelict state in the early 1960s, and to run a succession of old Rover cars. He will be greatly missed by all who had the good fortune to encounter him in any of his many roles, and most of all by his wife Margaret (well known to generations of students, visitors and other beneficiaries of the Longs' warm hospitality), son Peter, and two much-loved grandsons.

S.J.B. REED

\title{
J. D. H.Wiseman (1907-2002)
}

The Society has recently lost one of its most senior members. John Dugdale Holt Wiseman, who died on 14th October 2002 at the age of 95 , joined the Society in 1934 and was a Life Member at the time of his death, still retaining an interest in all three of the Society's major journals.

John Wiseman (Duggie to some) gained his $\mathrm{PhD}$ through the Department of Mineralogy and Petrology at Cambridge University in the early 1930s, studying under Professor C.E. Tilley and Dr A. Harker. His first paper was a contribution to the petrology of metamorphic rocks of East
Greenland, followed by several on related topics until he joined the staff of the Mineralogy Department at the British Museum (Natural History) in 1935, in the same year as G.F. Claringbull.

The Trustees of the Museum had decided in 1935 to separate the oceanic sediments, manganese nodules, and rocks from the much larger zoological collections and John Wiseman was recruited to curate and study the newly amalgamated ocean-bottom collections. The collection were based initially on material provided by Sir

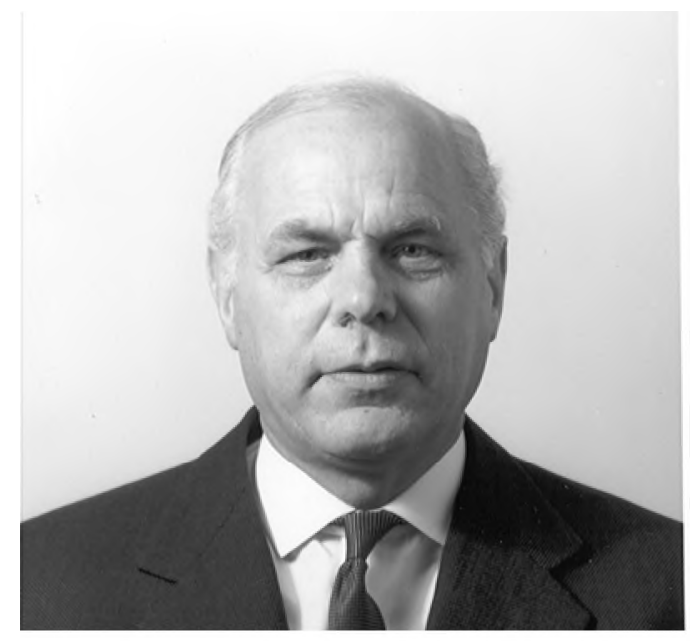


John Murray and from the Challenger expeditions, later boosted by material brought to the surface by ships of the Royal Navy. After working in the Admiralty during the Second World War he returned to the Museum but was heavily involved in developing UK oceanography, including the setting up of the Institute of Oceanography (then the National Institute of Oceanography). When he retired in 1972 John Wiseman was Deputy Keeper of the Mineralogy Department. The Museum records show that he had published 36 papers in his career.

It was John Wiseman who provided my introduction to the Mineralogy Department in 1969. He had been no mean athlete in his earlier years and would stride about the department with seemingly boundless energy. He had a habit of always jangling his substantial bunch of museum keys in his pocket as he walked around the department. This provided a warning of his approach to the staff and my memory of that first visit is that we hardly encountered a soul on our tour round the department. Had they all taken refuge in side rooms and store cupboards? I met him on a number of occasions after his retirement and he always retained a lively interest in the department and never failed to recall earlier discussions and dealings with his colleagues.

A.M. CLARK

\section{GEORGE RYBACK 1936-2003}

George Ryback was born in Russia on $10^{\text {th }}$ January 1936. Little is known of his early life in the Ukraine, he and his mother being reluctant to talk about it, but World War II caused major upheavals. His father was killed, his family never being informed, which was normal in Russia, and their home was over-run by the Germans. When the Red Army advanced, young George with his mother Tanya and her mother, who came from the noble Razumovsky family, retreated into Bavaria. Here they experienced many nights sleeping in interconnected cellars to shelter from British air-raids. Soon after the end of the war they found their way to London, where they had some relatives in the De Freitas family. Tanya met and married a Ukrainian emigré baron who was the writer's godfather, who soon brought George and the writer together. We shared a keen interest in chemistry and minerals, which provided the basis for a friendship which was to last the rest of George's lifetime. Initially he understood very little English, but within six months he was remarkably literate. He attended St. Paul's School, Hammersmith, where he put the school's mineral collection into order, then proceeded to New College, Oxford, for his degree in chemistry, with subsidiary mineralogy, the latter being taught mostly by Peter Embrey. At

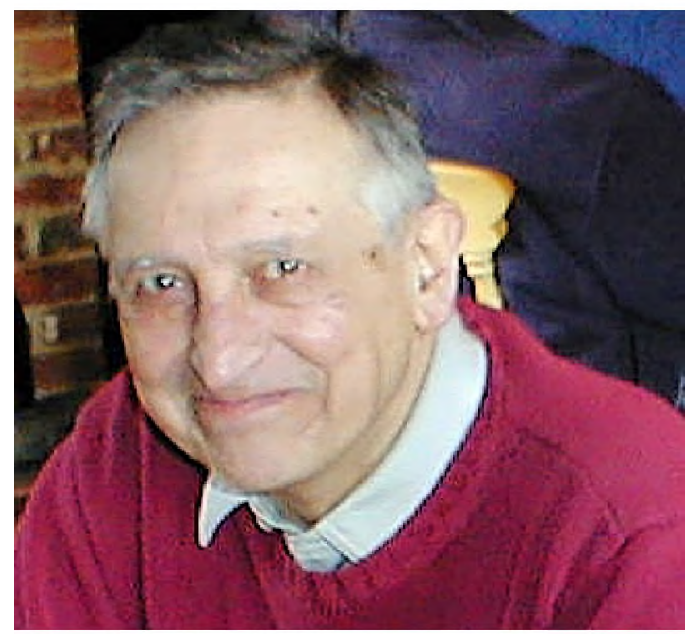

